\title{
Effect of Technological Conditions on Removing Organic Substances from Landfill Leachates
}

\author{
Justyna Koc-Jurczyk ${ }^{*}$, Łukasz Jurczyk', Magdalena Urbańska \\ 1 University of Rzeszow, Faculty of Biology and Agriculture, Department of Biological Basis of Agriculture and \\ Environmental Education, Cwiklinskiej 1a St., 35-601 Rzeszow, Poland \\ * Corresponding author's e-mail: jjurczyk@ur.edu.pl
}

\begin{abstract}
The paper presents the research on how the effectiveness of removing organic substances is affected by the use of polyurethane foam fillings characterized by a varied porosity and the temperature of the process of treating landfill leachate in a biological sequencing batch reactor. The information on the conversion of organic compounds during the operation of the reactor was obtained by measuring the absorbance for selected wavelengths to describe the process of humification. It was found that the technological conditions used in the experiment affected the effectiveness of reducing the COD, but did not affect the type or amount of the humic substances in the leachate treated. In all of the variants examined, the COD decreased the as the humification level increased, and yet this relation was not linear in character.
\end{abstract}

Keywords: municipal leachate, COD, humic substances

\section{INTRODUCTION}

According to the definition specified in the Directive of European Union Council on landfill sites, leachates are "any liquids seeping through the waste disposed of, and exuding from or contained in the landfill" (1999/31/EC). They are formed mainly as a result of water percolating through a landfill deposit from the outside, such as precipitation water, surface runoff water, and underground water. Additionally, leachates also originate from hydrolysis and biological decomposition of organic components present in the waste, as well as from wet materials disposed of at a landfill site (Grosser et al. 2015). By infiltrating a landfill, water leaches organic and mineral compounds therefrom, making it possible for the dissolved chemical compounds of various structures, origins, and different reactivity to occur in the leachates. As the time of waste being stored passes, new layers are being deposited and new cells formed, the chemical composition and concentration of particular components of the leachates change (Leszczyński 2014).
Humic substances (HS) are among the basic groups of chemical compounds identified in the leachates from municipal landfills, especially in the later phases of a waste deposit maturation (Krupińska 2012). HS are the products of the humification process of vegetable and animal particles. Being very complex, their chemical structure is difficult to identify in particular cases, having aliphatic or aromatic fragments of a varied degree of branching (Zhou, Meng 2015). They may have the form of organometallic complexes and chelates resistant to biological decomposition. In an aqueous environment, humic substances may be of autochthonous origin (formed as a product of natural changes in organic changes in the surface water), as well as allochtonic origin (reaching the water from external sources of different origins, including artificial ones) (Chmiel 2009). Until recently, HS were considered harmless, and if an effort was made to remove them, e.g. from drinking water, this was done mainly for refinement reasons. However, the research conducted in the recent years proved these compounds, having numerous functional groups in their structures, to 
be potential carriers of many organic substances, such as phthalates, inorganic substances including heavy metals (especially copper and lead ions), and toxic xenobiotics, such as pesticides (Yan et al. 2013).

Currently, there is no uniform systematics in the literature, with the classification most often based on to what extent the HS biopolymers present in sludge, soil and water are soluble in diluted bases, mineral acids, water, or alcohol. In view of the above, the substances are divided into three main groups:

a) humic acids (the term "humin acids" is also used and is sometimes understood as a mixture of humin and fulvic acids) - soluble in bases and coagulating at an acidification of $\mathrm{pH}>2$,

b) fulvic acids - soluble both in acids and in bases,

c) humins - existing only in soils and bottom sludge; cannot be extracted by bases or acids (Qi et al. 2012, Zhou, Meng 2015).

The quantitative analysis was carried out to evaluate the process of purging landfill leachates of HS using absorption parameters. Spectroscopic measurement is a cheap and quick optical method of determining the content of organic impurities. The measurement provides an absorption spectrum, indicating the relation between absorbance (Abs) and the wavelength $(\lambda)$ of the ray absorbed: $A b s=f(\lambda)$.

With the wavelengths of 280,465 and $665 \mathrm{~nm}$, the values of absorbance can be used to characterise humic substances by calculating dimensionless indicator as based on proportions: indicator $\mathrm{A}_{2 / 4}$ indicates the ratio of values at the wavelengths of 280 and $465 \mathrm{~nm}, \mathrm{~A}_{2 / 6}$ at the wavelengths of 280 and $665 \mathrm{~nm}$, and $A_{4 / 6}$ at the wavelengths 465 and $665 \mathrm{~nm}$. An increase in the value of each of these indicators is indicative of the transformation rate becoming lower and of a lower humification level of organic matter (Helms et al. 2008).

The main factor affecting the composition of leachates is the age of the landfill site. Given the conditions of neutralising impurities therein, especially important is the dynamics of the composition and concentration of organic substances, since the amount of biodegradable compounds decreases and the amount of compounds that are difficult to degrade increases as the landfill ages. There are numerous methods involving effective treatment of leachates at municipal waste landfill sites (Renou et al. 2009). These include the physicochemical methods, such as volume reduction by means of ultrafiltration and reverse osmosis
(Renou et al. 2009, Pi et al. 2009, Li et al. 2009) or evaporation, coagulation, flocculation or adsorption (Labanowski et al. 2010, Oloibiri et al. 2015), or a combination of these methods. From an economic standpoint, however, the biological methods based on the microbiological activity of the activated sludge suspended in the biofilm or settled on the biofilm, are most preferable when used in various types of reactors (Koc-Jurczyk 2014). One of the ways of retaining biomass in reactors and providing anaerobic and aerobic conditions is to use biomass carriers. Various media, such as Kaldnes (polyethylene media), Liapor (ceramic media) and Linpor (plastic media with a high porosity), or polyurethane (PU) foam cubes (Lim et al. 2011) can be used as biomass carriers. When waste is treated in the reactors with biomass carriers, the amount thereof is vital. With a complex porous structure and its highly developed inner surface, fillings in the form of PU foam enable organisms with various preferences for respiratory and nutritional substrates to settle the reactor faster and prevent the biomass from being leached excessively during an operation cycle. Biomass carriers contribute to a considerably larger growth of biomass and extend the age of activated sludge in the sequencing batch reactor. Larger surface area of carriers retains a larger amount of biomass in the reactor (Masłoń, Tomaszek 2015).

Landfill leachate is waste that is difficult to treat. In order to treat it effectively, biomass carriers are placed in SBR reactors or the temperature of the process is raised. The effectiveness of treatment can be determined on the basis of COD or the characteristics of humic substances defined by measuring absorbance with respective wavelengths. The paper is an attempt to determine whether the presence of a filling in the SBR and the temperature of the process affect the aforementioned indicators of the treated leachates.

\section{MATERIALS AND METHODS}

The leachates used for the tests came from the municipal landfill site in Kozodrza (50 $07^{\prime} 09^{\prime}$ 'N, $21^{\circ} 37^{\prime} 08^{\prime \prime} \mathrm{E}$ ), which has been in continuous use since 1990. Currently, it has the status of a Regional Municipal Waste Treatment Facility (RIPOK) for the western region of the Podkarpacie province, and receives approximately $90 \mathrm{Gg}$ of mixed municipal waste from 23 districts, including Rzeszow, on a yearly basis. Waste other than 
neutral and hazardous waste is disposed of at the landfill, with a cell designed for asbestos waste.

Leachates were taken form an impoundment reservoir, to which all of the closed quarters were drained, closed in tight 101 plastic containers, and immediately carried to the laboratory, where they were stored in the dark at $20^{\circ} \mathrm{C}$. Table 1 shows the characteristics of the organic compounds contained in the raw leachates from the municipal waste landfill in Kozdorza, based on the chemical oxygen demand (COD) indicator and the values obtained from spectrometry measurement.

Technological tests of treating the leachate were carried out in four sequential batch reactors (SBR1-4) of a working volume of 21 . All of the reactors involved a 24-hour operating cycle consisting of the phases of filling (15 min), aerating $(23 \mathrm{~h})$, setting $(0.5 \mathrm{~h})$, and decantation (15 $\mathrm{min})$, and the stopping time was 2 days.

SBR1 and SBR3 reactors were provided with PU (polyurethane) foam fillings with the pore density of 15 ppi (pore per linear inch) whereas SBR2 and SBR4 reactors had 30ppi. The filling consisted of 6 permanently fixed cuboidal inserts, with their volume fully submerged in the waste. The size of the inserts was such that they had the same total inner area of cells $\left(\approx 1800 \mathrm{~cm}^{2}\right)$, with different outer dimensions $(3 \times 3 \times 5$ and $3 \times 3 \times 8 \mathrm{~cm}$, respectively). The inner area of the inserts was calculated according to the Koc-Jurczyk and Jurczyk (2017) methodology with regard to foam of a structure close the Waeir-Phelan structure.

Provided with individual temperature-stabilising heating systems and fine-bubble aerating systems, the reactors were stirred mechanically. In SBR1 and SBR2 reactors, the experiment was conducted at a temperature of $25^{\circ} \mathrm{C} \pm 1$, while in SBR3 and SBR4 reactors, the temperature was $35^{\circ} \mathrm{C} \pm 1$. During the experiment, the efflux samples were taken once a week and the following was determined: the concentration of organic substances as expressed with the chemical oxy- gen demand (COD) according to the PN-ISO 6060:2006 standard and the optical properties of the aqueous solution as regards the wavelengths of 254, 265, 280, 320, 465 and $665 \mathrm{~nm}$ (UV-1800 Shimadzu). In order to determine the optical density, an efflux solution was prepared of a ratio of 1:10 in deionised water (SolPur), and the measurement was conducted in a quartz cuvette with a $1 \mathrm{~cm}$ light way length (Jena).

Due to the characteristics of the data obtained (distribution and sample size), a Mann-WhitneyWilcoxon semi-nonparametric test was carried out to perform a statistical analysis of the differences in the values of the COD indicator between the effluxes of the reactor pairs with different working temperatures and filling densities, as well as the correlation between the COD indicator values and the optical density of the leachate solutions was examined by means of the Pearson statistics (SOFA Statistics 1.5.4).

\section{RESULTS AND DISCUSSION}

The landfill site in Kozdorza is well-organised and has a well-developed infrastructure, also with regard to the facilities for the effective and safe drainage and storage of leachates. The leachates that were biologically treated in the experiment described are drained form closed cells at different stages of the rehabilitation work. Individual cells contain mixed waste which was disposed of in successive years and had different compositions resulting from an increase in the amount and the quality of waste on the one hand, and the improving degree of reclamation on the other hand. Hence, the leachates obtained have a composition of organic substances that is characteristic for a stable phase.

The tests focused on analysing the effect that such technological parameters as working temperature and the density of the biomass carrier

Table 1. Characteristics of the organic compounds in the raw leachates on the basis of the chemical oxygen demand and the absorbance at selected wavelengths

\begin{tabular}{|c|c|c|c|c|c|c|}
\hline COD [mg/l] & $A_{254}$ & $A_{265}$ & $A_{280}$ & $\mathrm{~A}_{320}$ & $A_{465}$ & $A_{665}$ \\
\hline 4700 & 13.75 & 10.6 & 10.6 & 6.32 & 1.3 & 0.56 \\
\hline & & & & & \multicolumn{2}{|c|}{$\begin{array}{c}\mathrm{A}_{4 / 6} \\
2.321\end{array}$} \\
\hline & & & \multicolumn{3}{|c|}{$\begin{array}{c}A_{2 / 4} \\
8.154\end{array}$} & \\
\hline & & & \multicolumn{4}{|c|}{$\begin{array}{c}\mathrm{A}_{2 / 6} \\
18.929\end{array}$} \\
\hline
\end{tabular}


used had on the effectiveness of removing humic substances from leachates in a biological process, with the content of organic substances indicated by COD employed as a reference.

As shown by the statistical analysis of the results, there are considerable differences in the concentration of the organic substances in the effluxes in the case of both different filling densities (15 ppi and $30 \mathrm{ppi}$ ) of the reactors operating at the same temperatures (SBR 1 and SBR 2, $p=0.006$, as well as SBR3 and SBR4, $p=0.006$ ) and the temperatures $\left(25\right.$ and $\left.35^{\circ} \mathrm{C}\right)$ of the operation of the reactors with the same filling density (SBR 1 and SBR3 $p=0.004$, as well as SBR2 and SBR4 $p=0.009$, respectively) (Table 2).

It is clear from the analysis of Figure 1 presenting changes in the content of the organic compounds and the optical density of the leachate solutions in the effluxes of the reactors during the experiment - that a decrease in the COD value observed for 1-2 weeks of the SBR operation is accompanied by an increase in the absorbance value (an increase in the concentration of humic substances), an increase that is especially noticeable in the middle and far ultraviolet ranges, 254 to 320 $\mathrm{nm}$, and less noticeable in visible blue and yellow. However, this relation is not linear in character (only in 3 cases the Pearson correlation was relevant, with the assumption that $p<0.01$; in SBR1 for $\alpha=254, r=-0.77$ with $p=0.005$, and for $\alpha=$ $320, r=-0.75$ with $p=0.008$, and in SBR3 for $\alpha$ $=265, r=-0.74$ with $p=0.008$ ), but its waveform was close to a multinomial model, and the value of the determination coefficient $\mathrm{R}^{2}$ ranged from 0.24 to 0.94 , with a median of 0.62 (Fig. 2).

In all of the reactors, the efflux became stable $(<5 \%$ difference in successive days of the experiment) on the 35 th day of the process. SBR1 $(52.5 \%)$ was found to be the most effective in removing general organic substances, and SBR2 a bit less effective (41.34\%, both operating at a temperature of $25^{\circ} \mathrm{C}$ ), and the reactors operating at a higher temperature of $35^{\circ} \mathrm{C}$ were found to be less effective. This may result from a large load of ammonia nitrogen, which may become transformed into a free form in higher temperatures $\left(\mathrm{NH}_{3}\right.$ gas) that may hamper the microbiological activity of the activated sludge.

When the effect of the density of a filling on the effectiveness of removing organic substances from the leachates was analysed, it was found that at a lower temperature, a filling of a greater density reduced the performance of the reactor considerably (11 per cent points). At higher temperature, a larger density of a filing resulted in a small increase in the effectiveness of treatment (Table 2, Figure 3).

Humic substances are a considerable part of organic matter in landfill leachates from later phases of use, as well as in the products of biological treatment of landfill leachates, irrespective of their age.

A large group of organic substances that commonly exist in water, such as HS, lignins, tannins and aromatic compounds, exhibit strong absorbance of waves with a length of $254 \mathrm{~nm}$ (Chmiel 2009). In contrast, absorbance is not exhibited by, among others, esters, sugars, alcohols, saturated carboxylic acids and their derivatives, and many others. It is widely assumed that absorbance at $280 \mathrm{~nm}\left(\mathrm{~A}_{280}\right)$ results from the content of compounds of a structure of lignins in the alkaline extract, with larger values $\mathrm{A}_{280}$ attesting to the presence of compounds that undergo humification with difficulty.

The absorbance value $\mathrm{A}_{465}$ reflects the content of substances at the initial stage, being positively correlated with the amount of young forms of humin acids which are formed at an early stage of the organic matter transformation. The coefficient value $\mathrm{A}_{665}$ enables to define the content of substances characterised by a large degree of humification (Chmiel 2009, Krupińska 2012).

Table 2. Influence of the filling density and the temperature of the operation of the SBR reactors on the reduction of the COD of the leachates

\begin{tabular}{|c|c|c|c|c|}
\hline Reactor & SBR1 & SBR2 & SBR3 & SBR4 \\
\hline Temperature $\left[{ }^{\circ} \mathrm{C}\right]$ & \multicolumn{2}{|c|}{25} & \multicolumn{2}{|c|}{35} \\
\hline $\begin{array}{l}\text { Declared ppi parameter [pores per } \\
\text { linear inch] }\end{array}$ & 15 & 30 & 15 & 30 \\
\hline COD [mg/l] & $2233.33 \pm 136.06$ & $2756.96 \pm 52.78$ & $3194.7 \pm 38.69$ & $3032.1 \pm 36.76$ \\
\hline Efficiency [\%] & 52.48 & 41.34 & 32.03 & 35.48 \\
\hline \multirow{3}{*}{ Statistic M-W } & \multicolumn{2}{|c|}{$p=0.006$} & \multicolumn{2}{|c|}{$p=0.006$} \\
\hline & \multicolumn{2}{|r|}{$p=0.004$} & \multirow{2}{*}{$\bar{p}=\overline{0.009}$} & \\
\hline & & & & \\
\hline
\end{tabular}



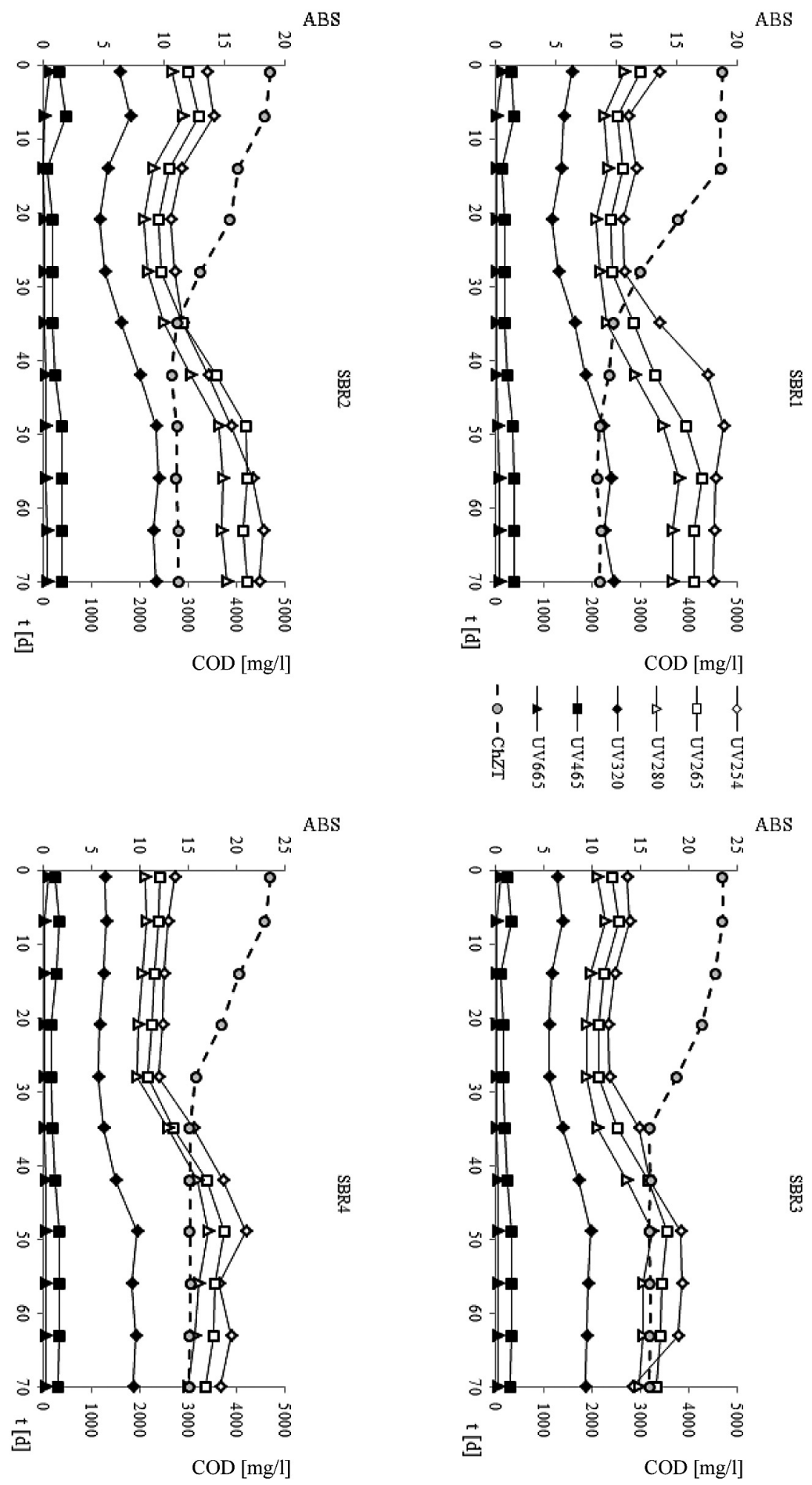

Figure 1. Changes in the values of absorbance and the chemical oxygen demand for selected wavelengths ( $\dot{\alpha}=254,265,280,320,465$ and $665 \mathrm{~nm})$ in the effluxes of particular reactors (SBR1-4)

during the experiment (70d)

As it is shown by the analysis of the results obtained, neither the presence of a filling in the SBR nor the temperature of the process affected the absorbance values (Table 3 ). This proves that the technological conditions of the process of treating the landfill leachates in a SBR do not affect the type of amount of humic substances.
Coefficients $\mathrm{A}_{2 / 4}, \mathrm{~A}_{2 / 6}$ and $\mathrm{A}_{4 / 6}$ are parameters that may be used to evaluate the progress of the humification process of organic matter. Young humin acids are characterised by larger values of these coefficients as compared to the acids with a high degree of humification. In the tests, the COD being reduced correlated with the reduction 
Table 3. Effect of the density of a filling and the temperature of the operation of the SBR reactors on the absorbance at selected wavelengths

\begin{tabular}{|c|c|c|c|c|}
\hline Reactor & SBR1 & SBR2 & SBR3 & SBR4 \\
\hline Temperature $\left[{ }^{\circ} \mathrm{C}\right]$ & \multicolumn{2}{|c|}{25} & \multicolumn{2}{c|}{35} \\
\hline $\mathrm{A}_{254}$ & $17.35 \pm 1.93$ & $17.68 \pm 2.66$ & $17.74 \pm 1.9$ & $18.34 \pm 1.76$ \\
\hline $\mathrm{A}_{265}$ & $15.09 \pm 2.22$ & $15.48 \pm 2.18$ & $16.2 \pm 1.88$ & $16.8 \pm 1.8$ \\
\hline $\mathrm{A}_{280}$ & $13.2 \pm 2.32$ & $13.5 \pm 2.05$ & $14.3 \pm 2.02$ & $14.4 \pm 1.42$ \\
\hline $\mathrm{A}_{320}$ & $8.5 \pm 1.28$ & $8.6 \pm 1.2$ & $8.94 \pm 1.06$ & $8.59 \pm 1.38$ \\
\hline $\mathrm{A}_{465}$ & $1.28 \pm 0.3$ & $1.32 \pm 0.32$ & $1.41 \pm 0.3$ & $1.43 \pm 0.28$ \\
\hline $\mathrm{A}_{665}$ & $0.22 \pm 0.07$ & $0.23 \pm 0.07$ & $0.25 \pm 0.05$ & $0.23 \pm 0.06$ \\
\hline $\mathrm{A}_{2 / 4}$ & 10.43237 & 10.55373 & 10.25402 & 11.03583 \\
\hline $\mathrm{A}_{2 / 6}$ & 64.42219 & 59.71615 & 57.83769 & 67.72728 \\
\hline $\mathrm{A}_{4 / 6}$ & 6.118738 & 5.638789 & 5.636403 & 6.085049 \\
\hline
\end{tabular}
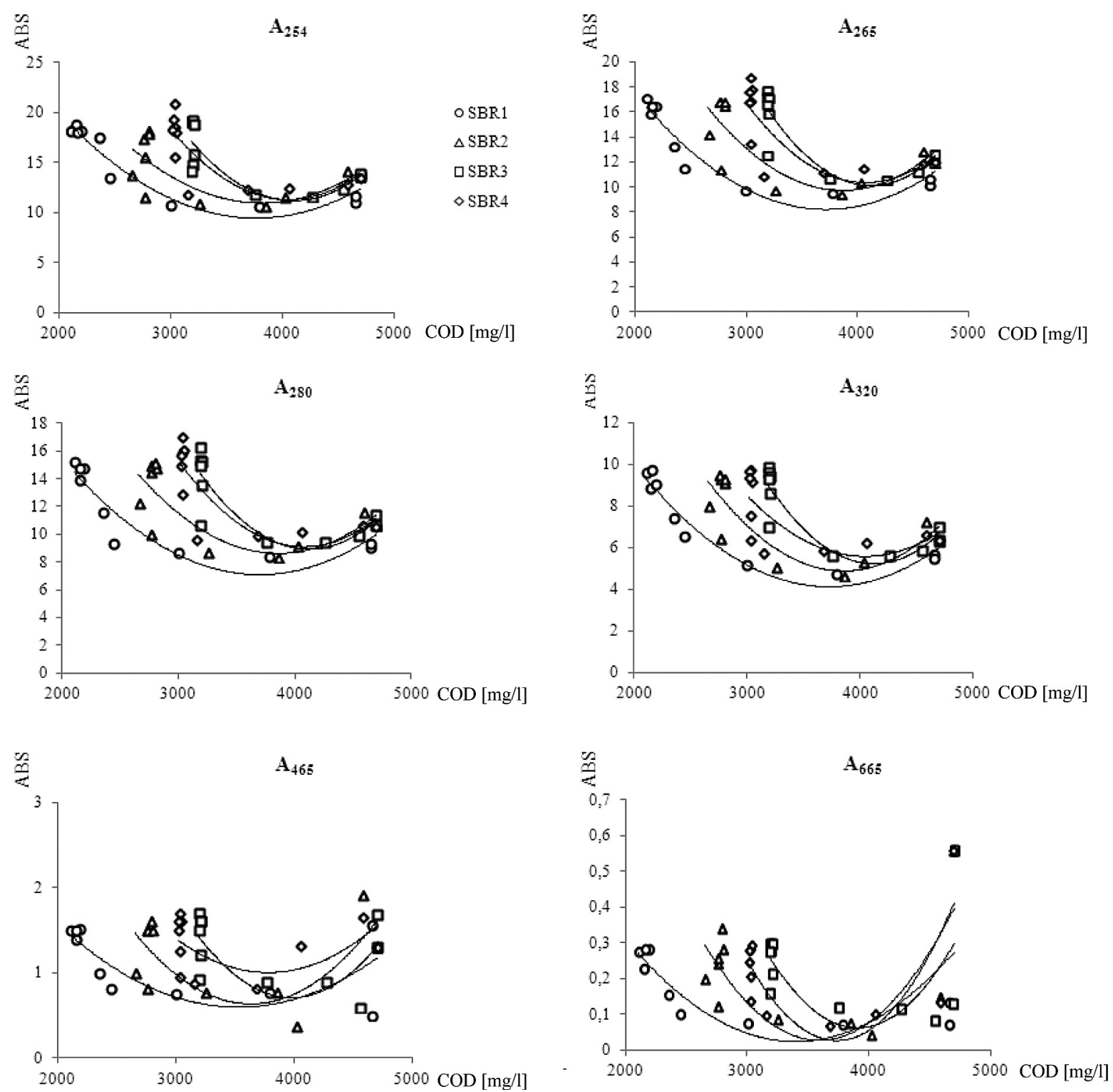

Figure 2. Relation between the absorbance for selected wavelengths ( $\alpha=254,265,280,320,465$ and $665 \mathrm{~nm})$ and the content of organic compounds (COD) in the effluxes from individual reactors (SBR1-4) 

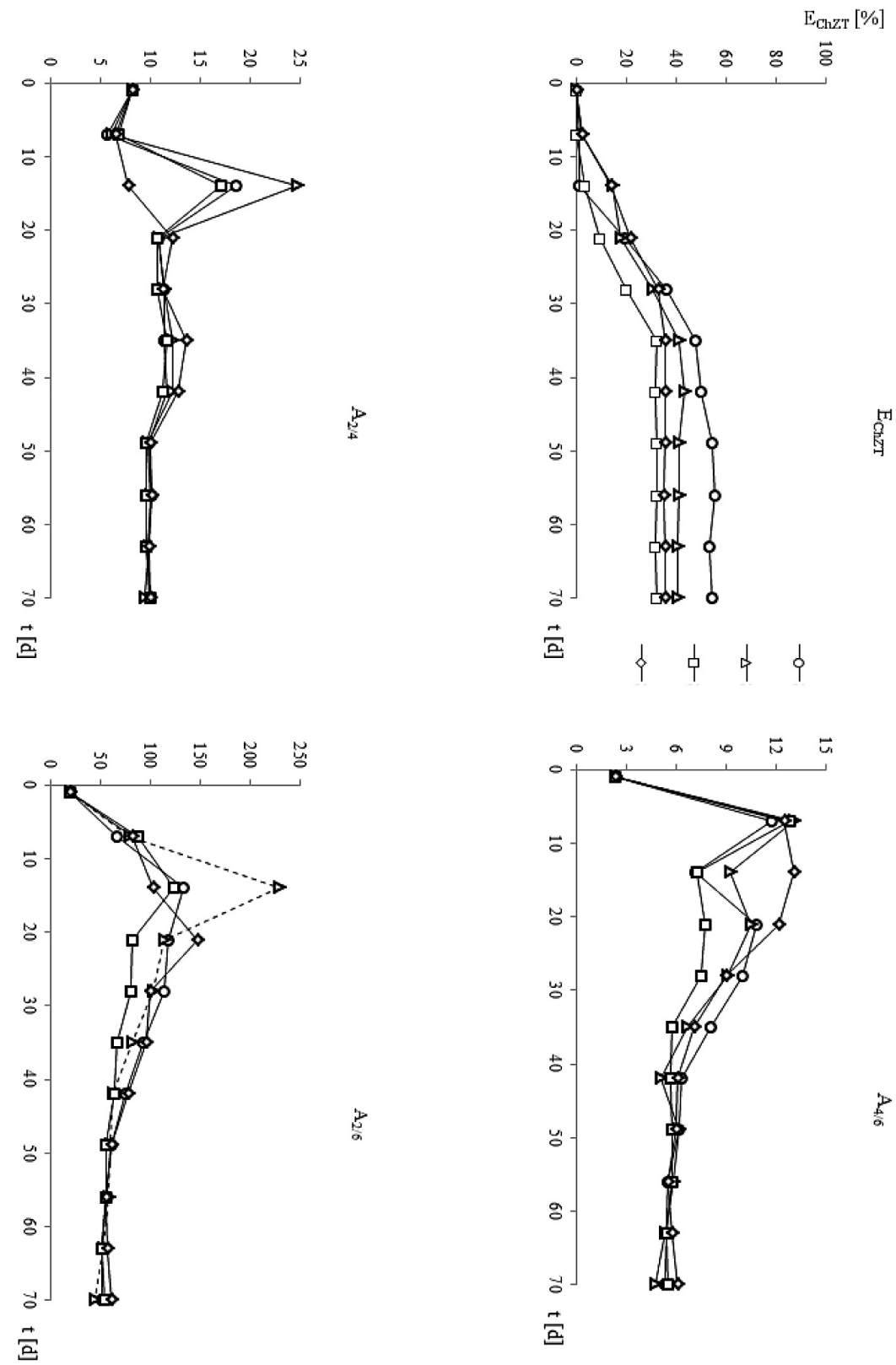

Figure 3. Dynamics of the changes in the effectiveness of removing organic compounds as expressed by COD and the values of the indicators of the decomposition of organic compounds on the basis of the ratio of optical density A2/4, A2/6 and A4/6 during the experiment (70d)

of coefficients $\mathrm{A}_{2 / 4}, \mathrm{~A}_{2 / 6}$ and $\mathrm{A}_{4 / 6}$ in the leachates. It was found that the technological conditions of the process of treating the leachates did not affect the coefficient values of the leachates treated (Table 3, Figure 3).

According to Chen et al. (2002), high coefficient $\mathrm{A}_{2 / 4}$ results mainly from the absorption of functional groups $\mathrm{C}=\mathrm{O}$. A low value may result from the aromatic functional groups $\mathrm{C}=\mathrm{C}$ absorbing compounds with a high condensation of aromatic rings and a large molecular weight in particular. Indicator $A_{4 / 6}$ enables to estimate general characteristics of HS. According to Ste- venson, quotient $\mathrm{A}_{4 / 6}$ should be treated as humification indicators. The degree of the humification of HS may be defined on the basis of the curves of optical density. A higher optical density coincides with a larger amount of humin acids distinguished by a high optical density. Ratio $\mathrm{A}_{4 / 6}$ for humin acids is usually smaller than 5.0, and for fulvic acids, is in the range of 6.0 to 8.5 . It is assumed that the values of indicator $\mathrm{A}_{4 / 6}$ decrease as the molecular weight of humus compounds or as the degree of the polymerisation of the nucleus thereof increases. For this reason, colour quotient $\mathrm{A}_{4 / 6}$ may be used as an indicator of the humification degree (Chmiel 2009). 


\section{CONCLUSIONS}

The highest effectiveness of reducing COD was almost $53 \%$, which would not be considered an achievement with ordinary municipal waste, but with the leachates from a stabilised municipal waste landfill which were distinguished by a large proportion of hardly degradable organic carbon forms, it was a satisfactory value. Additionally, it should be stressed that only the technology of active sludge was used, aided by plastic fillings, without an external carbon source nor without raising the bioavailability of organic compounds by means of physicochemical methods. As the efficiency of removing organic compounds increased, a spectrophotometric analysis enabled to trace the progress of the humification process. In all of the leachates treated in each reactor, the values of the absorbance of waves 254,265 , 280, 320, 465 and $665 \mathrm{~nm}$ increased as the COD dropped, which showed that the amount of compounds of a simpler structure that were difficult to degrade, rose.

\section{REFERENCES}

1. Chen, J., Gu, B., LeBooeuf, E., Pan, H., Dai, S., 2002. Spectroscopic characterization of the structural and functional properties of natural organicmatter fractions. Chemosphere, 48, 59-68.

2. Chmiel A. 2009. Wpływ biochemicznych przemian zanieczyszczeń na ich podatność na koagulację. Praca doktorska, Politechnika Wrocławska, Wydział Inżynierii Środowiska, Wrocław.

3. Grosser A., Jelonek P., Neczaj E. 2015. Trendy w oczyszczaniu odcieków składowiskowych. $\mathrm{W}$ : Interdyscyplinarne zagadnienia w inżynierii i ochronie środowiska 5 (red.) Wiśniewski J., Kutyłowska M., Trusz-Zdybek A., Oficyna Wydawnicza Politechniki Wrocławskiej.

4. Helms J.R., Stubbins A., Ritchie J.D., Minor E.C., Kieber D.J., Mopper K., 2008. Absorption spectral slopes and slope ratios as indicators of molecular weight, source, and photobleaching of chromophoric dissolved organic matter. Limnol.Oceanogr., 53, 955-969.

5. Koc-Jurczyk J. 2014. Removal of refractory pollutants from landfill leachate using two-phase system. Water Environtal Research, 86, 74-80.

6. Koc-Jurczyk J., Jurczyk Ł. 2017. Biological treatment of landfill leachate at elevated temperature in the presence of polyurethane foam of various porosity. Clean - Soil, Air, Water, 45, 1-8.
7. Krupińska I. 2012. Problemy związane z występowaniem substancji humusowych w wodach podziemnych. Inżynieria Środowiska, 28, 55-72.

8. Labanowski J., Pallier V., Feuillade-Cathalifaud G. 2010. Study of organic matter during coagulation and electrocoagulation processes: Application to a stabilized landfill leachate. Journal of Hazardous Materials, 179, 166-172.

9. Leszczyński J. 2014. Zastosowanie siarczanu żelaza(II) i nadtlenku wodoru do podczyszczania odcieków składowiskowych. Inżynieria Ekologiczna, 43, 75-79.

10. Li F., Wichmann K., Heine W. 2009. Treatment of the methanogenic landfill leachate with thin open channel reverse osmosis membrane modules. Waste Management, 29, 960-964.

11. Lim J.W., Seng C.E., Lim P.E., Ng S.L., Sujari A.N.A. 2011. Nitrogen removal in moving bed sequencing batch reactor using polyurethane foam cubes of various sizes as carrier materials. Bioresource Technology, 102, 9876-9883.

12. Masłoń A., Tomaszek J. A. 2015 A study on the use of the BioBall ${ }^{\circledR}$ as a biofilm carrier in a sequencing batch reactor, Bioresource Technology, 196, 577-585.

13. Oloibiri V., Ufomba I., Chys M., Audenaert W.T.M., Demeestere K., van Hulle S.W.H. 2015. A comparative study on the efficiency of ozonation and coagulation-flocculation as pretreatment to activated carbon adsorption of biologically stabilized landfill leachate. Waste Management, 43, 335-342.

14. Pi K.W., Gao L.X., Fan M.X., Gong W.Q., Wan D.J. 2009. Two-stage biodegradation coupled with ultrafiltration for treatment of municipal landfill leachate. Process Safiety and Environmental Protection, 87, 336-342.

15. PN-ISO 6060:2006 Jakość wody - Oznaczanie chemicznego zapotrzebowania tlenu/ Water quality - Determination of chemical oxygen demand.

16. Qi G., Yue D., Nie Y. 2012. Characterization of humic substances in bio-treated municipal solid waste landfill leachate. Frontiers of Environmental Science \& Engineering, 6, 711-716.

17. Renou S., Poulain S., Givaudan J.G., Moulin P. 2009. Amelioration of ultrafiltration process by lime treatment: Case of landfill leachate. Desalination, 249, 72-82.

18. Yan M., Wang D., Korshin G.V., Benedetti M.F. 2013. Quantifying metal ions binding onto dissolved organic matter using log-transformed absorbance spectra. Water Research, 47, 2603-2611.

19. Zhou M., Meng F. 2015. Using UV-vis absorbance spectral parameters to characterize the fouling propensity of humic substances during ultrafiltration. Water Research, 87, 311-319. 